Pak. j. sci. ind. res. Ser. A: phys. sci. 2016 59(2) 63-75

\title{
(E)-N'-(2, 4-dihydroxybenzylidene)nicotinohydrazide and its Metal Complexes: Synthesis, Characterisation and Antitubercular Activity
}

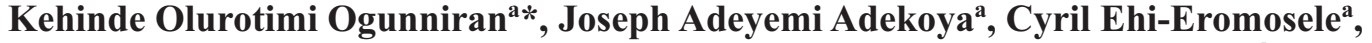 \\ Olayinka Oyewale Ajani ${ }^{a}$, Akinlolu Kayode ${ }^{a}$ and Tadigoppula Narender ${ }^{b}$ \\ ${ }^{a}$ Department of Chemistry, College of Science and Technology, Covenant University, \\ PMB, 1023, Ota, Ogun State, Nigeria \\ ${ }^{b}$ Medicinal and Process Chemistry Division, CSIR-Central Drug Research Institute, Lucknow, India
}

(received April 15, 2015; revised August 6, 2015; accepted August 7, 2015)

\begin{abstract}
Nicotinic acid hydrazide and 2,4-dihydoxylbenzaldehyde were condensed at $20{ }^{\circ} \mathrm{C}$ to form an acylhydrazone $\left(\mathrm{H}_{3} \mathrm{~L}^{1}\right)$ with $\mathrm{ONO}$ coordination pattern. The structure of the acylhydrazone was elucidated by using CHN analyzer, ESI mass spectrometry, IR, ${ }^{1} \mathrm{H}$ NMR, ${ }^{13} \mathrm{C}$ NMR and $2 \mathrm{D}$ NMR such as COSY and HSQC. Thereafter, five novel metal complexes [Mn(II), Fe(II), Pt(II) Zn(II) and Pd(II)] of the hydrazone ligand were synthesized and their structural characterization were achieved by several physicochemical methods namely: elemental analysis, electronic spectra, infrared, EPR, molar conductivity and powder X-ray diffraction studies. An octahedral geometry was suggested for both $\mathrm{Pd}(\mathrm{II})$ and $\mathrm{Zn}(\mathrm{II})$ complexes while both $\mathrm{Mn}$ (II) and Fe(II) complexes conformed with tetrahedral pyramidal. However, Pt(II) complex agreed with tetrahedral geometry. In vitro antitubercular activity study of the ligand and the metal complexes were evaluated against Mycobacterium tuberculosis, H37Rv, by using micro-diluted method. The results obtained revealed that $\left(\mathrm{PtL}^{1}\right)(\mathrm{MIC}=0.56 \mathrm{mg} / \mathrm{mL}),\left(\mathrm{ZnL}^{1}\right)(\mathrm{MIC}=0.61 \mathrm{mg} / \mathrm{mL}),\left(\mathrm{MnL}^{1}\right)(\mathrm{MIC}=0.71 \mathrm{mg} / \mathrm{mL})$ and $\left(\mathrm{FeL}^{1}\right)(\mathrm{MIC}=0.82 \mathrm{mg} / \mathrm{mL})$, exhibited a significant activity when compared with first line drugs such as isoniazid $(\mathrm{INH})(\mathrm{MIC}=0.9 \mathrm{mg} / \mathrm{mL}) . \mathrm{H}^{2} \mathrm{~L}^{1}$ exhibited lesser antitubercular activity with MIC value of $1.02 \mathrm{mg} / \mathrm{mL}$. However, the metal complexes displayed higher cytotoxicity but were found to be nonsignificant different $(\mathrm{P}>0.05)$ to isoniazid drug.
\end{abstract}

Keywords: hydrazones, metal complexes, electron spin resonance, thermogravimetry, powder X-ray diffraction, antitubercular agents

\section{Introduction}

Human tuberculosis (TB) has re-emerged with devastating consequences on global public health and it is currently one of the most widespread infectious diseases. In addition, it is the leading cause of death due to a single infectious agent among human adults in the world (Jenkins et al., 2011). Mycobacterium tuberculosis is one of the most harmful pathogens of mankind, infecting onethird of the global population and claiming two million lives every year (Stewart et al., 2003). Tuberculosis spreads by aerosols from patients with pulmonary disease (Phillip and Graham, 2004). Mycobacterial infection has increased in number worldwide due to a global increase in the number of patients with HIV infection and AIDS disease, increase in number of elderly patients and the emergence of resistant tuberculosis. Tuberculosis arises in two different ways: either from a recent infection with $M$. tuberculosis or from the reactivation of dormant

*Author for correspondence;

E-mail: kehinde.ogunniran@covenant-university.edu.ng tubercle bacillus after initial infection. As a consequence, the present level of tuberculosis comprises both individuals with "new" exogenous infections and those with a reactivation of "old" endogenous disease (De Backer et al., 2006). In terms of absolute number of TB cases, 22 countries of the world have the highest TB burden with at least 270 cases per 100,000 populations. Among the top five ranking countries are India, China, Indonesia, South Africa and Nigeria (Harper, 2007; Laughon, 2007). The situation has become more deplorable than it appeared as 0.5 million new cases due to multidrugresistant (MDR) TB were recorded in 2010 (WHO, 2013). The alarming estimates exposes that 0.22 billion people may acquire TB and 79 million could die due to TB by the year 2030 .

Effective TB treatment is difficult, due to the unusual structure and chemical composition of the Mycobacterium cell wall, which makes many antibiotics ineffective and hinders the entry of drugs (Jia et al., 2005). TB disease can be treated by taking several drugs for 6 to 9 months 
which includes the first 2 months of isoniazid, rifampicin, pyrazinamide, and ethambutol in the intensive phase and after that period isoniazid and rifampicin in the continuous phase (Jindani et al., 2004). Most of the drugs in the current tuberculosis regime result from the research performed over 50 years ago (Sacchettini et al., 2008). With the global emergence of multidrug-resistant tuberculosis (MDR-TB) and extensively drug-resistant tuberculosis (XDR-TB) there is an urgent need to develop new anti-mycobacterial agents.

In the search for new compounds, isoniazid derivatives have been found to possess potential tuberculostatic activities (Aboul-Fadl et al., 2011). Hydrazones are important compounds for drug design, as possible ligands for metal complexes, organocatalysis and also for the syntheses of heterocyclic compounds. These compounds have interesting biological properties, such as anti-inflammatory, analgesic, anticonvulsant, antituberculous, antitumor, anti-HIV and antimicrobial activity (Nataliya et al., 2010). In the present work, an acylhydrazone obtained in the reaction of nicotinic hydrazide with 2,4-dihydroxybenzaldehyde and its $\mathrm{Mn}(\mathrm{II}), \mathrm{Fe}(\mathrm{II}), \mathrm{Pt}(\mathrm{II}) \mathrm{Zn}$ (II) and $\mathrm{Pd}(\mathrm{II})$ complexes were characterised and tested for their antimycobacterial activity. The presence of the hydrazine pharmacophore in these compounds is expected to contribute to high antimycobacterial activity.

\section{Materials and Methods}

Measurements. All the chemicals and solvents used were reagent grade and used without further treatment unless otherwise noted. Nicotinic acid hydrazide and 2,4-dihydroxylbenzaldehyde were purchased from Sigma-Aldrich. ESI-MS spectrum of the ligand was obtained using Agilent 6520 Q-TOF mass spectrometer. The $\%$ of carbon, nitrogen and hydrogen in the synthesized hydrazones and metal complexes were determined by using Vario EL CHNS analyzer. ${ }^{1} \mathrm{H},{ }^{13} \mathrm{C}$ and $2 \mathrm{D}$ NMR (COSY, HSQC and DEPT 135) spectra of the hydrazone were recorded by using Bruker AMX 300 FT-NMR spectrometer with DMSO-d6 at sophisticated analytical instruments facility, Central Drug Research Institute, Lucknow, India. The infrared spectroscopy of the hydrazone and the metal complexes were recorded on Perkin-Elmer RX-1 Fourier Transform Infrared Spectrometer using $\mathrm{KBr}$ pellets in the range of $4000-400 \mathrm{~cm}^{-1}$. The electronic data of the hydrazone and the metal complexes were obtained in methanol/DMSO by using Perkin Elmer Spectro UV-visible Double Beam UVD spectrometer in the range of 200-700 $\mathrm{nm}$. The molar conductivities of the metal complexes at ambient temperature in DMF solution $\left(10^{-3} \mathrm{M}\right)$ were measured using systronics-304 conductivity meter at Chemistry Department, Covenant University, Canaan Land, Sango-Ota, Ogun State, Nigeria. The magnetic measurements of paramagnetic metal complexes in powder form were measured at room temperature by using vibrating susceptibity magnometer (PAR 155) with magnetic field of -10 to $+10 \mathrm{kOe}$ at Instrumentation Center, Indian Institute of Technology, Roorkee, India. TGA/DTA thermograph of the metal complexes were obtained by heating the complexes at the rate of $10^{\circ} \mathrm{C} / \mathrm{min}$ under inert atmosphere by using thermogravimetric analyzer TGA Q500 V20.8 Build 34 model at Indian Institute of Science and Technology, Hyderabad, India. The EPR spectra of the metal complexes at $77 \mathrm{~K}$ were recorded on a Varian E-112 spectrometer using TCNE as the standard, with 100 $\mathrm{KHz}$ modulation frequency, modulation amplitude $2 \mathrm{G}$ and $9.1 \mathrm{GHz}$ microwave frequency at sophisticated analytical instruments facility, Indian Institute of Technology, Bombay, India. Powder X-ray diffraction data for one of the metal complexes were collected by using Powder X-ray diffractometer at Instrumentation center, Indian Institute of Technology, Roorkee, India. Powder diffraction data was recorded on a Bruker AXS D8 Advance diffractometer operating in the $\theta: \theta$ mode, equipped with a secondary beam graphite monochromator, a $\mathrm{Na}(\mathrm{Tl}) \mathrm{I}$ scintillation counter, and pulse-height amplifier discrimination. $\mathrm{CuK} \alpha$ radiation $(\lambda=1.5418 \AA)$ was used. The X-ray generator and diffractometer settings were $40 \mathrm{kV}, 40 \mathrm{~mA}$, DS $0.5^{\circ}$, AS $0.5^{\circ}$, and RS $0.1 \mathrm{~mm}$. Experimental conditions were step scan mode, with $5<\theta<105^{\circ}, \Delta \theta=0.02^{\circ}$, and $\mathrm{t}=30 \mathrm{~s} / \mathrm{step}$. Silicon NBS $640 \mathrm{~b}$ was used as an external standard.

Synthesis of (E)- $N^{\prime}$-(2,4-dihydroxybenzylidene) nicotinohydrazide. The synthetic methods previously described by Cui et al. (2012) were modified and adopted. The nicotinic acid hydrazide ( $10 \mathrm{mmol}, 1.37 \mathrm{~g}$ ) was dissolved in $20 \mathrm{~mL}$ of absolute ethanol by heating gently on water bath. The solution obtained was mixed with ethanolic solution of 2,4-dihydroxylbenzaldehyde (10 $\mathrm{mmol}$ ) in a round bottom flask. The mixture was stirred at $20^{\circ} \mathrm{C}$ for $6 \mathrm{~h}$ after which it was allowed to stand at ambient temperature for $24 \mathrm{~h}$. The precipitate formed was filtered and washed several times with ethanol. The precipitate was recrystallized in mixture of methanol and chloroform (1:1). It was filtered off, washed with ether and dried in vacuum. The purity of the hydrazone 
was confirmed by single spot displayed by TLC using methanol: chloroform (2:8) mixture.

Yield $1.82 \mathrm{~g}$ (70.8\%); light pink solid; mp: $273-275^{\circ} \mathrm{C}$; $\mathrm{R}_{\mathrm{f}}=0.83\left(\mathrm{CHCl}_{3} / \mathrm{CH}_{3} \mathrm{OH}, 4: 1\right.$, at RT. $) .{ }^{1} \mathbf{H}-\mathbf{N M R}$ (DMSO-d6) $\delta: 12.16\left(\mathrm{~s},{ }^{1} \mathrm{H}, \mathrm{NH}\right), 11.36\left(\mathrm{~s},{ }^{1} \mathrm{H}, \mathrm{Ar}-\right.$ $\left.\mathrm{OH}_{(2)}\right), 10.06$ (s, $\left.{ }^{1} \mathrm{H}, \mathrm{Ar}-\mathrm{OH}_{(3)}\right), 9.10\left(\mathrm{~s},{ }^{1} \mathrm{H}, \mathrm{H}(4)\right), 8.80$ (d, J=3.84 Hz, $\left.{ }^{1} \mathrm{H}, \mathrm{H}(5)\right), 8.55$ (s, ${ }^{1} \mathrm{H}, \mathrm{H}-\mathrm{CN}$ ), 8.30 ( dt, $\left.J=7.9 \mathrm{~Hz},{ }^{1} \mathrm{H}, \mathrm{H}(7)\right), 7.60\left(\mathrm{dd}, J_{1}=4.80 \mathrm{~Hz}, J_{2}=7.9\right.$ $\left.\mathrm{Hz},{ }^{1} \mathrm{H}, \mathrm{H}(8)\right), 7.39$ (d, $\left.J=8.43 \mathrm{~Hz},{ }^{1} \mathrm{H}, \mathrm{H}(9)\right) 6.42$ (dd, $\left.J_{l}=2.1 \mathrm{~Hz}, J_{2}=8.43 \mathrm{~Hz} .{ }^{1} \mathrm{H}, \mathrm{H}(10)\right) 6.36\left(\mathrm{~d}, J=2 .{ }^{1} \mathrm{~Hz}\right.$, ${ }^{1} \mathrm{H}, \mathrm{H}(11)$ ) ppm. ${ }^{13} \mathbf{C}-\mathrm{NMR}$ (DMSO-d6) $\delta$ : $161.3(\mathrm{C} 1$ ), 161.2 (C2), 159.8 (CO), 159.3 (C4), 149.9 (C5), 148.8 ( $\mathrm{NCH}), 135.6$ (C7), 131.6 (C8), 129.1 (C9), 123.9 (C10), 110.7 (C11), 108.1 (C12), 102.9 (C13) ppm. IR $(\mathrm{KBr}) \mathrm{cm}^{-1}$ : $3432(\mathrm{ArOH}), 3158(\mathrm{NH}), 1639(\mathrm{C}=\mathrm{O})$, $1508(\mathrm{C}=\mathrm{N}), 1466(\mathrm{~N}-\mathrm{N}), 1353(\mathrm{C}-\mathrm{O}), 1165(\mathrm{C}-\mathrm{N}) . \mathrm{MS}$ (ESI+): in $\mathrm{m} / \mathrm{z}: 258.0[\mathrm{M}+\mathrm{H}]^{+}$. Anal. calcd. for $\mathrm{C}_{14} \mathrm{H}_{12} \mathrm{~N}_{3} \mathrm{O}_{3}$ (256.26): C, 65.62; H, 4.68; N, 16.39 . Found: C, 65.89; H, 4.53; N, 16.16 (Scheme 1).

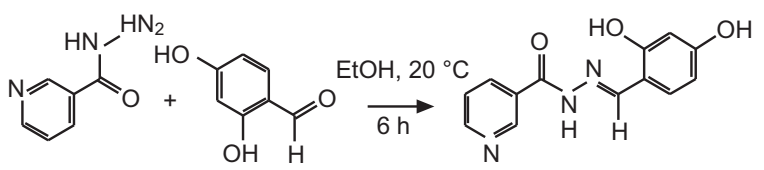

Scheme 1. Synthetic pathway for $\mathrm{H}_{3} \mathrm{~L}^{1}$.

Preparation of Mn(II), Fe(II), $\mathrm{Pt}(\mathrm{II}), \mathrm{Zn}$ (II) and $\operatorname{Pd}\left(\right.$ II) complexes of $(E)-N^{\prime}$-(2,4-dihydroxybenzylidene) nicotinohydrazide $\left(\mathrm{H}_{3} \mathrm{~L}^{1}\right)$. [Mn $\left.\left(\mathrm{H}_{3} \mathrm{~L}^{1}\right)_{2}\right] \cdot \mathrm{H}_{2} \mathrm{O}$ (1). To an ethanolic solution of $\mathrm{H}_{3} \mathrm{~L}^{1}(10$ mmole, $2.57 \mathrm{~g})$, 10 mmole equivalent of $\left[\mathrm{Mn}\left(\mathrm{CH}_{3} \mathrm{COO}\right)_{2} \cdot 4 \mathrm{H}_{2} \mathrm{O}\right]$ dissolved in absolute ethanol were added slowly after which 2 drops of TEA was added. The mixture was refluxed at $80{ }^{\circ} \mathrm{C}$ for $4 \mathrm{~h}$. The brown product obtained was allowed to stand at ambient temperature for $24 \mathrm{~h}$ after which it was filtered, washed with absolute ethanol followed by ether and dried over $\mathrm{P}_{4} \mathrm{O}_{10}$ in vacuo.

[Fe $\left(\boldsymbol{H}_{3} \boldsymbol{L}^{1}\right)_{2} \boldsymbol{C l}_{2}$ ] (2). $10 \mathrm{mmol}(2.57 \mathrm{~g})$ of ethanolic solution of $\mathrm{H}_{3} \mathrm{~L}^{1}$ was dissolved in absolute ethanol and mixed directly ethanolic solution of anhydrous $\mathrm{FeCl}_{2}$ $(10 \mathrm{mmol}, 1.27 \mathrm{~g})$. The mixture was refluxed at $80^{\circ} \mathrm{C}$ for $5 \mathrm{~h}$. The solution obtained was allowed to stand at ambient temperature for $48 \mathrm{~h}$. The black precipitate formed was filtered and washed thrice with $30 \mathrm{~mL}$ of cold ethanol, followed by ether and dried in vacuo.

[Pt $\left(\mathrm{H}_{3} \mathbf{L}^{1}\right) \mathbf{C l} \boldsymbol{C l}$ (3). 10 mmole (2.66 g) of $\mathrm{PtCl}_{2}$ was heated to dryness in $1 \mathrm{~mL}$ of conc. $\mathrm{HCl}$ in a round bottom flask, after which $10 \mathrm{~mL}$ of distilled water was added. The mixture was stirred at $60{ }^{\circ} \mathrm{C}$ for $30 \mathrm{~min}$ before adding ethanolic solution of $\mathrm{H}_{3} \mathrm{~L}^{1}(10 \mathrm{mmol}$, $2.57 \mathrm{~g}$ ) in $10 \mathrm{~mL}$ of absolute ethanol. The mixture was then refluxed for $3 \mathrm{~h}$. The green precipitate formed was filtered after cooling the solution in ice blocks, washed with $30 \mathrm{~mL}$ of cold ethanol and dried over $\mathrm{P}_{4} \mathrm{O}_{10}$ in vacuo.

[ $\left.\mathrm{Zn}\left(\mathrm{H}_{3} \mathrm{~L}^{\mathbf{I}}\right)\left(\mathrm{CH}_{3} \mathrm{COO}\right)_{2} \mathrm{H}_{2} \mathrm{O}\right]$ (4). $10 \mathrm{mmol}(1.83 \mathrm{~g})$ of $\mathrm{Zn}\left(\mathrm{CH}_{3} \mathrm{COO}\right)_{2}$ was dissolved in $20 \mathrm{~mL}$ of mixture of absolute ethanol and distilled water (1:1). The solution obtained was added gradually to ethanolic solution of $\mathrm{H}_{3} \mathrm{~L}^{1}$ (10 mmol in $20 \mathrm{~mL}$ of ethanol) in a round bottom flask after which two drops of TEA were added. The solution was refluxed at $80^{\circ} \mathrm{C}$ for $4 \mathrm{~h}$. The yellow precipitate formed was allowed to cool to ambient temperature after which it was filtered, washed with $30 \mathrm{~mL}$ of ethanol and then with $10 \mathrm{~mL}$ of ether. The precipitate was then dried by using vacuum rotary evaporator.

[Pd( $\left.\boldsymbol{H}_{3} \boldsymbol{L}^{1}\right) \boldsymbol{C l}$ (5). $10 \mathrm{mmol}(1.77 \mathrm{~g})$ of $\mathrm{PdCl}_{2}$ was dissolved in $10 \mathrm{~mL}$ of DMF while $10 \mathrm{mmol}$ of $\mathrm{H}_{3} \mathrm{~L}^{1}$ was dissolved in $10 \mathrm{~mL}$ of absolute ethanol. The solutions were mixed together in a round bottom flask and refluxed at $80{ }^{\circ} \mathrm{C}$ for $6 \mathrm{~h}$ after which the solution was left at room temperature for $48 \mathrm{~h}$. The dark brown precipitate formed was filtered and washed with cold ethanol and then dried over $\mathrm{P}_{4} \mathrm{O}_{10}$ in vacuo.

Antimycobacterial activity study. MIC determination. All the compounds were screened for their in vitro antimycobacterial activities against isoniazid (ATCC 35822) resistant strains of $M$. tuberculosis, using the micro plate Alamar Blue assay (MABA) (Sivakumar and Rajasekaran, 2013). A serial dilution of the compounds was made directly on the plate. The final drug concentrations tested were $0.01-20.0 \mu \mathrm{g} / \mathrm{mL}$. The plates were covered and sealed with parafilm and incubated at $37^{\circ} \mathrm{C}$ for 5 days. After this time, $25 \mu \mathrm{L}$ of a freshly prepared 1:1 mixture of Alamar Blue reagent and 10\% tween 80 was added to the plate and incubated for $24 \mathrm{~h}$. A blue colour in the well indicated no bacterial growth, and a pink colour indicated growth. The minimal inhibition concentration (MIC) was defined as the lowest drug concentration, which prevented a colour change from blue to pink.

Cytotoxicity study. Cytotoxicity of $\mathrm{H}_{3} \mathrm{~L}^{1}$ and some of its synthesized metal complexes were determined with the Vero cell line ATCC CCL-81 using an MTS assay (Protopopova et al., 2005). 


\section{Results and Discussion}

Mass spectrum of $\mathbf{H}_{3} \mathbf{L}^{1}$. The molecular mass of the hydrazone was ascertained with the use of mass spectrum obtained by the use of Agilent 6520 Q-TOF mass spectrophotometer (ESI). The spectrum (Fig. 1) showed the molecular ion peak at $\mathrm{m} / \mathrm{z} 258.0$ which is in agreement with the calculated molecular mass of the compound within the precision limit of \pm 0.02 .

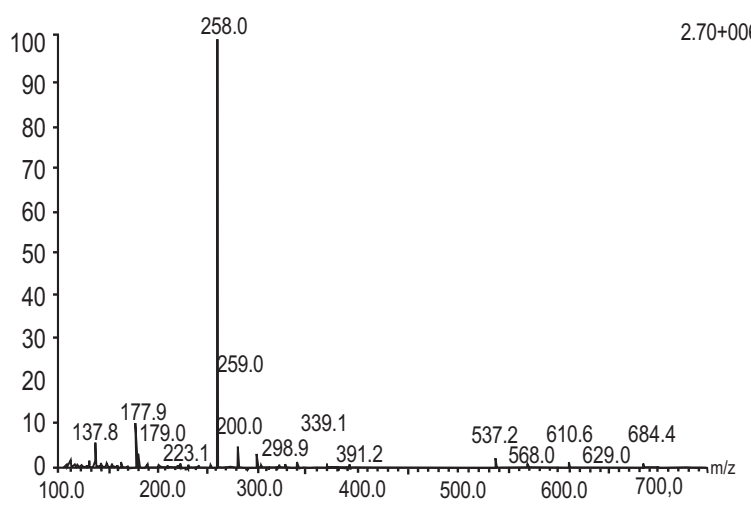

Fig. 1. ESI mass spectrum for $\mathrm{H}_{3} \mathrm{~L}^{1}$.

${ }^{1} \mathbf{H}$ NMR spectrum of $\mathbf{H}_{3} \mathbf{L}^{1}$. The ${ }^{1} \mathrm{H}$ NMR spectrum of the hydrazone (Fig. 2) showed a sharp singlet peak which integrated as one hydrogen at $\delta=12.16 \mathrm{ppm}$. It was assigned to an imine proton $\mathrm{NH}(1)$ (Pavia et al., 2008). Apart from the fact that the proton is attached to a highly electronegative element, the effect of neighboring atoms contributed to a high decrease in electron density around the imine proton (Sankar et al., 2010; Jursic et al., 2002). The infrared spectrum confirmed the involvement of the imine proton in interhydrogen bonding formation with hydroxyl group $\left(\mathrm{NH}^{\cdots} \mathrm{OH}\right)$ during tautomerism and thereby contributing to decrease in electron density around the proton. Thus, the proton resonated downfield (Mustafa et al., 2009). The singlet peak observed was as a result of the absence of protons on its neighbouring atoms and thus there was no coupling interaction. The two other singlet peaks in the downfield region of the spectrum at $11.36 \mathrm{ppm}$ and $10.06 \mathrm{ppm}$ were assigned to the two aromatic protons $\mathrm{OH}(2)$ and OH(3), respectively (Al-Shaalan, 2011; Patel and Patel, 2011). The high $\delta$ ppm values could be attributed to their attachment to high electronegative element and thereby making each of the peaks to resonate as a single peak downfield. Also in the pyridine moiety, H(4) resonated as a single peak with a slight shoulder at $9.10 \mathrm{ppm}$.
Other aromatic protons resonated within the region $8.80-6.36 \mathrm{ppm}$. The doublet of doublet peak which integrates as one proton at $7.60 \mathrm{ppm}$ was assigned to proton $\mathrm{H}(8)$ which is at the meta position to nitrogen atom in the pyridine moiety. The splitting observed is as a result of the coupling effect from adjacent protons. The doublet peak at $8.8 \mathrm{ppm}$ was assigned to a proton $\mathrm{H}(5)$ at the ortho position to $\mathrm{N}(1)$ atom in the pyridine moiety. The doublet signal observed was attributed to the coupling effect from proton $\mathrm{H}(8)$ which is at the meta position. The doublet of triplet peak at $8.30 \mathrm{ppm}$ was assigned to the proton $\mathrm{H}(7)$ which is adjacent to $\mathrm{N}(1)$ atom. Also, the proton in between the two aromatic group $\mathrm{H}(9)$ was assigned to a doublet peak at $7.39 \mathrm{ppm}$. The doublet peak observed is as a result meta coupling effect from $\mathrm{H}(10)$. Meanwhile, $\mathrm{H}(10)$ was assigned to doublet of a doublet at $6.42 \mathrm{ppm}$, while a doublet at $6.36 \mathrm{ppm}$ was assigned to $\mathrm{H}(11)$. The proton at $6.42 \mathrm{ppm}$ experienced meta coupling effect from $\mathrm{H}(9)$ and ortho coupling effect from $\mathrm{H}(11)$ and therefore resonated as doublet of doublet. Also the doublet signal at $6.36 \mathrm{ppm}$ assigned to $\mathrm{H}(11)$ resulted from the ortho coupling effect from proton $\mathrm{H}(10)$ at $6.42 \mathrm{ppm}$.

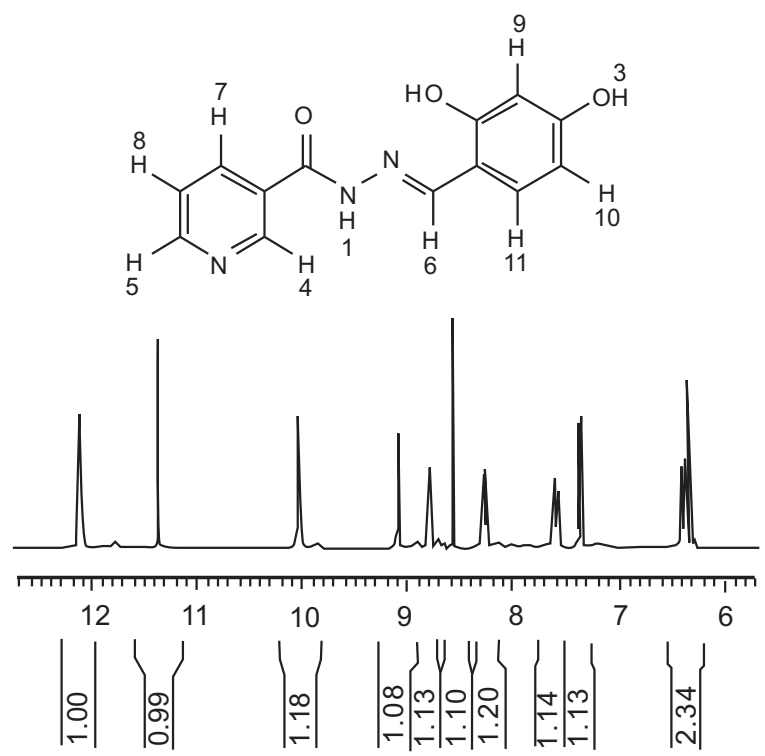

Fig. 2. ${ }^{1} \mathrm{HNMR}$ spectrum of $\mathrm{H}_{3} \mathrm{~L}^{1}$ recorded in DMSO-d6 at $300 \mathrm{MHz}$.

COSY spectrum of $\mathbf{H}_{\mathbf{3}} \mathbf{L}^{\mathbf{1}}$. The COSY experiment was used to confirm the protons assignment above. The COSY spectrum shown in Fig. 3 revealed the ${ }^{1} \mathrm{H}-{ }^{1} \mathrm{H}$ coupling interactions in the molecule (Berger and Sicker, 2009; 
Silverstein and Webster, 2002). The absence of off diagonal peak at 12.10, 11.36, 10.04, 9.10 and $8.54 \mathrm{ppm}$ confirmed their assignment to $\mathrm{H}(1), \mathrm{ArOH}(2), \operatorname{ArOH}(3)$, $\mathrm{H}(4)$ and $\mathrm{H}(6)$, respectively. This confirmed that absence of coupling interaction around the protons in the molecule. However, COSY spectrum confirmed that the multiplet peak at $7.60 \mathrm{ppm}$, assigned to $\mathrm{H}(8)$, experienced coupling interaction with a doublet of triplet peak at $8.30 \mathrm{ppm}$ and at the same time correlated with a doublet peak at $8.80 \mathrm{ppm}$. The two peaks were assigned to $\mathrm{H}(7)$ and $\mathrm{H}(5)$, respectively. COSY spectrum also confirmed that the proton at $6.42 \mathrm{ppm}$ correlated with $\mathrm{H}(9)$ at $7.39 \mathrm{ppm}$ and and $\mathrm{H}(11)$ at $6.36 \mathrm{ppm}$, respectively. The resonances at $6.42 \mathrm{ppm} \mathrm{H}(10)$ and $6.36 \mathrm{ppm} \mathrm{H}(11)$ confirmed that the two protons were attached to neighboring carbon atoms. The schematic contour plot of ${ }^{1} \mathrm{H}-$ ${ }^{1} \mathrm{H}$ COSY experiment for $\mathrm{H}_{3} \mathrm{~L}{ }^{1}$, (Fig. 3), along with the observed coupling interaction is given in (Fig. 4).

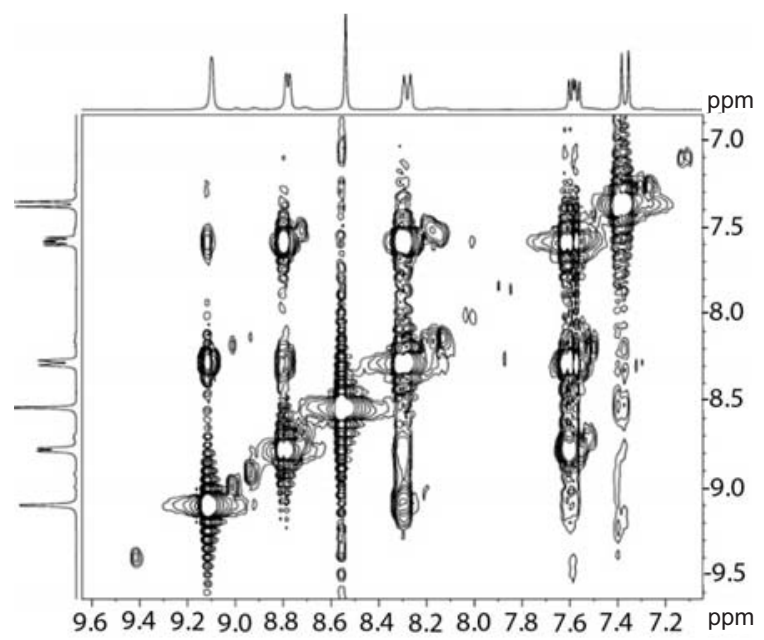

Fig. 3. ${ }^{1} \mathrm{H}-{ }^{1} \mathrm{H}$ COSY spectrum of $\mathrm{H}_{3} \mathrm{~L}^{1}$ at $300 \mathrm{MHz}$.

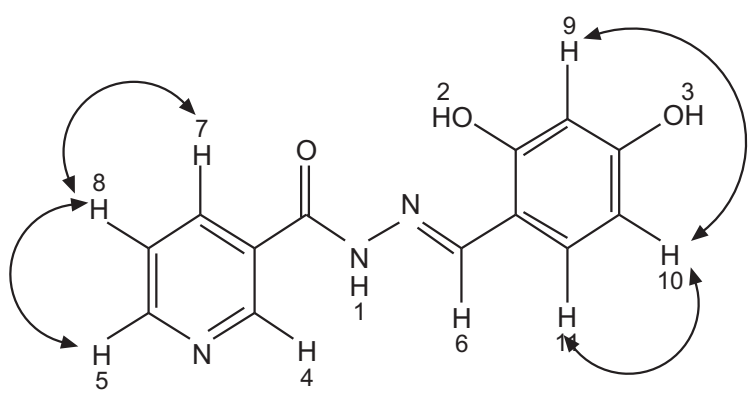

Fig. 4. ${ }^{1} \mathrm{H}-{ }^{1} \mathrm{H}$ COSY spectrum schematic structure of $\mathrm{H}_{3} \mathrm{~L}^{1}$.
${ }^{13} \mathrm{C}$ NMR spectrum of $\mathrm{H}_{3} \mathrm{~L}^{1}$. The ${ }^{13} \mathrm{C}$ NMR spectrum (Fig. 5) displayed the presence of 13 magnetically different carbon atoms in the molecule which corresponded to the number of carbon atoms in the molecule. The assignments were done on the basis of proton decoupled ${ }^{13} \mathrm{C}$ spectrum. The two carbon atoms attached to hydroxyl group in the resorcinol ring $[\mathrm{C}(1)$ and $\mathrm{C}(2)]$ resonated at $162.12 \mathrm{ppm}$ and $160.95 \mathrm{ppm}$ downfield, respectively due to the effect of the attached electronegative element coupled with the fact that both carbons are $\mathrm{sp}^{2}$ carbon. Thus, a high decrease in electron density around the two carbon atoms is expected. Also, the peak at 159.56 ppm was assigned to the carbonyl carbon, $\mathrm{C}(3)$, which appeared downfield due to the conjugative effect of $\mathrm{N}(2)-\mathrm{N}(3)$ core in the hydrazone. The two adjacent carbon atoms to $\mathrm{N}(1)$ appeared downfield at $152.31 \mathrm{ppm}$ and $149.65 \mathrm{ppm}$, respectively, because both of them were affected by electronegative effect of $\mathrm{N}(1)$. The lower field of carbon atom, $148.56 \mathrm{ppm}, \mathrm{C}(6)$ is due to extensive $\pi$ electron delocalization of $\mathrm{N}(2)-\mathrm{N}(3)=\mathrm{C}(6)$ bond chain. The remaining two carbons in the pyridine moiety, $C(7)$ and $C(10)$, were assigned to the peak at $135.37 \mathrm{ppm}$ and $123.62 \mathrm{ppm}$, respectively. The resonances assigned to resorcinol carbons are $\mathrm{C}(8), 131.32 ; \mathrm{C}(12), 107.84$; $\mathrm{C}(13), 102.71 \mathrm{ppm}$. The non-protonated carbons, $\mathrm{C}(11)$ and $\mathrm{C}(9)$, resonated downfield due to the conjugative effect of $\mathrm{C}(6)=\mathrm{N}(3)$ on $\mathrm{C}(11)$ and electronic effect exerted by adjacent carbonyl on $\mathrm{C}(9)$.

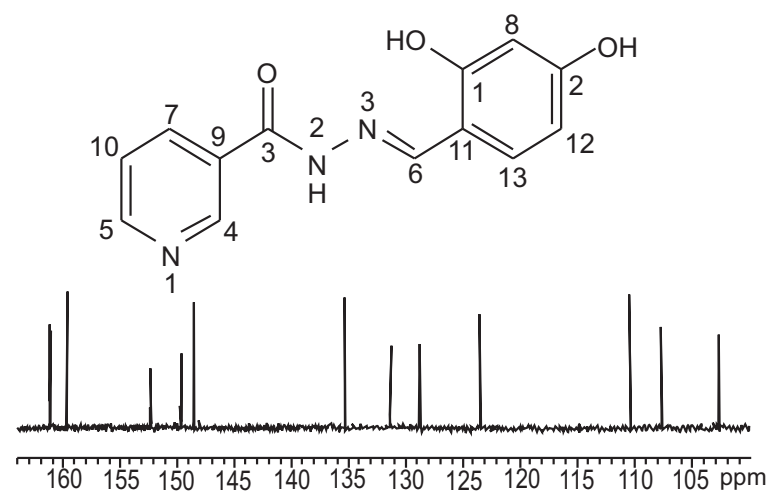

Fig. 5. ${ }^{13} \mathrm{C}$ NMR spectrum of $\mathrm{H}_{3} \mathrm{~L}^{1}$ in DMSO-d6 at $75 \mathrm{MHz}$.

${ }^{1} \mathrm{H}^{13} \mathbf{C}$ HSQC spectrum of $\mathrm{H}_{3} \mathrm{~L}^{1} \cdot{ }^{1} \mathrm{H}-{ }^{13} \mathrm{C}$ correlation spectrum (Fig. 6) was used to confirm both the proton and carbon assignments. HSQC spectrum showed all the protonated carbon in the molecule. Only 8 carbon 


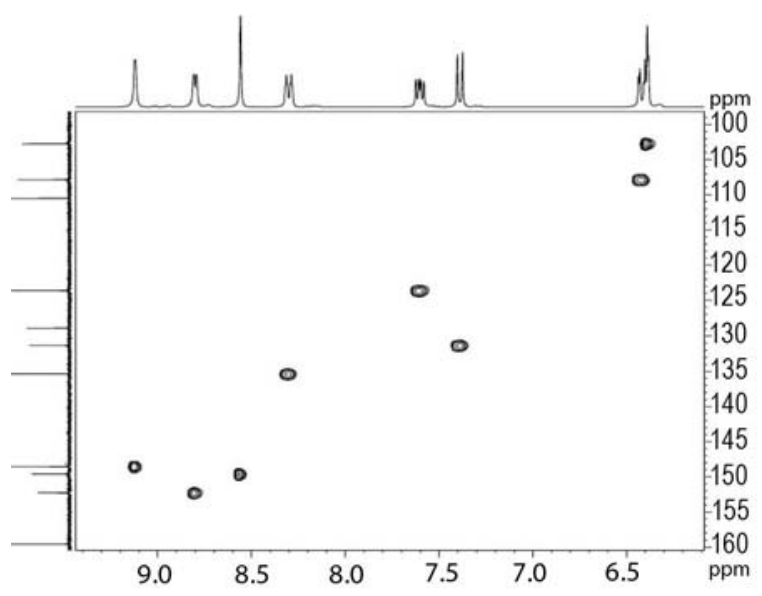

Fig. 6. ${ }^{1} \mathrm{H}-{ }^{13} \mathrm{C}$ COSY spectrum of $\mathrm{H}_{3} \mathrm{~L}^{1}$ at $75 \mathrm{MHz}$.

atoms appeared in the correlated spectrum and this matches the structure of the hydrazone. ${ }^{13} \mathrm{C}$-NMR peaks at $161.12,160.95,159.55,128.85$ and $110.49 \mathrm{ppm}$ did not make any correlation in the HSQC spectrum and therefore suggested that these carbons are non-protonated as assigned. However, all the protonated carbons showed correlation with the attached proton at the assigned position. Based on this, the schematic diagram for the hydrazone ${ }^{1} \mathrm{H}-{ }^{13} \mathrm{C}$ relation is as shown in Fig. 7.

Analytical data of $\mathbf{H}_{3} \mathbf{L}^{1}$ metal complexes. All the metal complexes of $\mathrm{H}_{3} \mathrm{~L}^{1}$ synthesized possess characteristics colour as reported in Table 1. The metal complexes were found to possess high melting point $\left(300^{\circ} \mathrm{C}\right)$ due to the coordination bonds. They were found to be sparingly soluble in methanol, DMF and THF but are soluble in DMSO and pyridine. The results of elemental analyses
$(\mathrm{C}, \mathrm{H}, \mathrm{N})$ obtained are in good agreement with the calculated values. The magnetic susceptibility values recorded at room temperature for $\mathrm{Mn}$ (II) and $\mathrm{Ni}(\mathrm{II})$ complexes compete favourably with the calculated spin only magnetic values. The conductivity ability of the metal complexes is very low, thus suggesting nonelectrolytic character of the synthesized complexes.

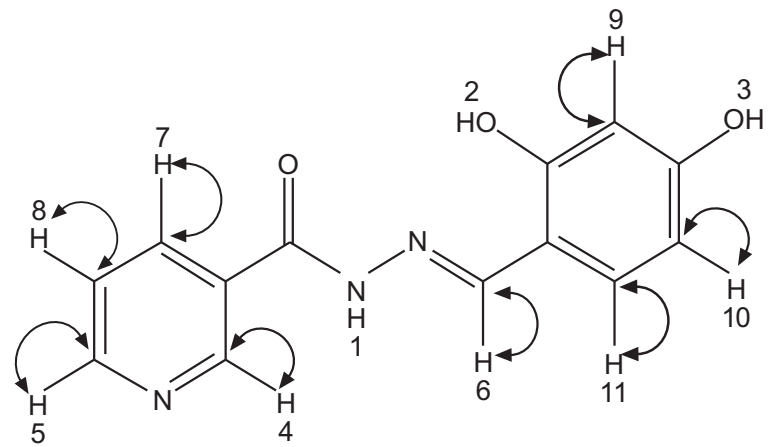

Fig. 7. Schematic diagram of ${ }^{1} \mathrm{H}-{ }^{13} \mathrm{C}$ COSY for $\mathrm{H}_{3} \mathrm{~L}^{1}$.

Infrared spectra. The spectra interpretation was done by comparing the spectra of each of the metal complexes with the spectrum of the ligand, $\mathrm{H}_{3} \mathrm{~L}^{1}$. The tentative infrared spectra assignments of $\mathrm{H}_{3} \mathrm{~L}^{1}$ and its metal complexes are presented in Table 2 while some of the spectra are shown in Fig. 8. The significant changes in the vibration bands of the metal complexes when compared to that of the ligand were observed by Davidson (2010). A strong peak at $3432.27 \mathrm{~cm}^{-1}$ attributed to $\mathrm{OH}$

Table 1. Analytical data of $\mathrm{H}_{3} \mathrm{~L}^{1}$ metal complexes

\begin{tabular}{|c|c|c|c|c|c|c|c|c|}
\hline \multirow[t]{2}{*}{ Complex } & \multirow{2}{*}{$\begin{array}{l}\text { Colour } \\
\text { (\% Yield) }\end{array}$} & \multirow{2}{*}{$\begin{array}{l}\text { M. pt. } \\
\left({ }^{\circ} \mathrm{C}\right)\end{array}$} & \multicolumn{4}{|c|}{ Found (Calc.), \% } & \multirow{2}{*}{$\begin{array}{l}\Lambda_{\mathrm{M}} \\
\mathrm{S} \mathrm{cm} / \mathrm{mol}\end{array}$} & \multirow{2}{*}{$\begin{array}{l}\mu_{\text {eff }} \\
\mu \mathrm{B}\end{array}$} \\
\hline & & & $\bar{M}$ & $\mathrm{C}$ & $\mathrm{H}$ & $\mathrm{N}$ & & \\
\hline$\left[\mathrm{Mn}\left(\mathrm{H}_{3} \mathrm{~L}^{1}\right)\left(\mathrm{CH}_{3} \mathrm{COO}\right)_{2}\right] \cdot \mathrm{H}_{2} \mathrm{O}(\mathbf{1})$ & $\begin{array}{l}\text { Brown } \\
(62.5)\end{array}$ & $>300$ & $\begin{array}{l}12.52 \\
(12.95)\end{array}$ & $\begin{array}{l}41.52 \\
(45.55)\end{array}$ & $\begin{array}{l}4.21 \\
(4.27)\end{array}$ & $\begin{array}{l}9.22 \\
(9.37)\end{array}$ & 32 & 5.82 \\
\hline$\left[\mathrm{Fe}\left(\mathrm{H}_{3} \mathrm{~L}^{1}\right) \mathrm{Cl}_{2}\right]$ (2) & $\begin{array}{l}\text { Black } \\
(51.2)\end{array}$ & $>300$ & $\begin{array}{l}14.12 \\
(14.58)\end{array}$ & $\begin{array}{l}40.59 \\
(40.77)\end{array}$ & $\begin{array}{l}3.22 \\
(2.63)\end{array}$ & $\begin{array}{l}10.72 \\
(10.97)\end{array}$ & 56 & 5.3 \\
\hline$\left[\mathrm{Pt}\left(\mathrm{H}_{3} \mathrm{~L}^{1}\right) \mathrm{C} 1\right] . \mathrm{Cl}(\mathbf{3})$ & $\begin{array}{l}\text { Green } \\
(65.0)\end{array}$ & $>300$ & $\begin{array}{l}36.89 \\
(37.28)\end{array}$ & $\begin{array}{l}29.51 \\
(29.84)\end{array}$ & $\begin{array}{l}2.04 \\
(2.12)\end{array}$ & $\begin{array}{l}7.53 \\
(8.03)\end{array}$ & 28 & - \\
\hline$\left[\mathrm{Zn}\left(\mathrm{H}_{3} \mathrm{~L}^{1}\right)\left(\mathrm{CH}_{3} \mathrm{COO}\right)_{2} \mathrm{H}_{2} \mathrm{O}\right](4)$ & $\begin{array}{l}\text { Yellow } \\
(78.8)\end{array}$ & $>300$ & $\begin{array}{l}14.17 \\
(14.26)\end{array}$ & $\begin{array}{l}41.73 \\
(41.51)\end{array}$ & $\begin{array}{l}4.27 \\
(4.17)\end{array}$ & $\begin{array}{l}9.56 \\
(9.16)\end{array}$ & 30 & - \\
\hline$\left[\mathrm{Pd}\left(\mathrm{H}_{3} \mathrm{~L}^{1}\right) \mathrm{C} 1\right](\mathbf{5})$ & $\begin{array}{l}\text { Brown } \\
(65.06)\end{array}$ & $>300$ & $\begin{array}{l}26.53 \\
(26.66)\end{array}$ & $\begin{array}{l}39.03 \\
(39.12)\end{array}$ & $\begin{array}{l}2.53 \\
(2.78)\end{array}$ & $\begin{array}{l}10.56 \\
(10.53)\end{array}$ & 26 & - \\
\hline
\end{tabular}

$\mathrm{L}^{1}=\mathrm{C}_{13} \mathrm{H}_{8} \mathrm{~N}_{3} \mathrm{O}_{3}$ 
Table 2. Infrared spectra assignments for metal complexes of $\mathrm{H}_{3} \mathrm{~L}^{1}$

\begin{tabular}{|c|c|c|c|c|c|c|}
\hline $\begin{array}{l}\text { Ligand/metal } \\
\text { complex }\end{array}$ & $\begin{array}{l}\mathrm{v}(\mathrm{OH}) \\
\mathrm{cm}^{-1}\end{array}$ & $\begin{array}{l}\mathrm{v}(\mathrm{C}=\mathrm{O}) \\
\mathrm{cm}^{-1}\end{array}$ & $\begin{array}{l}\mathrm{v}(\mathrm{C}=\mathrm{N}) \\
\mathrm{cm}^{-1}\end{array}$ & $\begin{array}{l}\mathrm{v}(\mathrm{N}-\mathrm{N}) \\
\mathrm{cm}^{-1}\end{array}$ & $\begin{array}{l}\delta(\mathrm{C}-\mathrm{O}) \mathrm{df} . \\
\mathrm{cm}^{-1}\end{array}$ & $\begin{array}{l}\delta(\mathrm{C}-\mathrm{N}) \mathrm{df} . \\
\mathrm{cm}^{-1}\end{array}$ \\
\hline $\mathrm{H}_{3} \mathrm{~L}^{1}$ & $3432.27 \mathrm{vs}$ & $1639.5 \mathrm{~s}, \mathrm{~b}$ & $1508.62 \mathrm{~m}$ & $1466.91 \mathrm{~m}$ & $1353.0 \mathrm{~s}$ & $1165.23 \mathrm{~s}$ \\
\hline$\left[\mathrm{Mn}\left(\mathrm{H}_{3} \mathrm{~L}^{1}\right)\left(\mathrm{CH}_{3} \mathrm{COO}\right)_{2} \mathrm{H}_{2} \mathrm{O}\right]$ (1) & $3402.5 \mathrm{~s}, \mathrm{~b}$ & $1660.01 \mathrm{~m}$ & $1574.32 \mathrm{~ms}$ & $1476.99 \mathrm{w}$ & $1354.03 \mathrm{~m}$ & $1181.03 \mathrm{~m}$ \\
\hline$\left[\mathrm{Fe}\left(\mathrm{H}_{3} \mathrm{~L}^{1}\right) \mathrm{Cl}_{2}\right](\mathbf{2})$ & $3396.89 \mathrm{~s}, \mathrm{~b}$ & $1593.74 \mathrm{~m}$ & $1539.29 \mathrm{~m}$ & $1438.24 \mathrm{w}$ & $1347.51 \mathrm{~m}$ & $1136.67 \mathrm{~s}$ \\
\hline$\left[\mathrm{Pt}\left(\mathrm{H}_{3} \mathrm{~L}^{1}\right) \mathrm{Cl}\right] . \mathrm{Cl}(\mathbf{3})$ & $3413.3 \mathrm{~s}, \mathrm{~b}$ & $1609.39 \mathrm{~m}$ & $1535.93 \mathrm{~m}$ & $1437.95 \mathrm{w}$ & $1212.35 \mathrm{~m}$ & $1129.2 \mathrm{~m}$ \\
\hline$\left[\mathrm{Zn}\left(\mathrm{H}_{3} \mathrm{~L}^{1}\right)\left(\mathrm{CH}_{3} \mathrm{COO}\right)_{2} \mathrm{H}_{2} \mathrm{O}\right]$ & $3414.47 \mathrm{~s}, \mathrm{~b}$ & $1604.31 \mathrm{~m}$ & $1524.69 \mathrm{w}$ & $1491.26 \mathrm{w}$ & $1374.39 \mathrm{~m}$ & $1190.56 \mathrm{~s}$ \\
\hline$\left[\mathrm{Pd}\left(\mathrm{H}_{3} \mathrm{~L}^{1}\right) \mathrm{Cl}\right](\mathbf{5})$ & $3384.43 \mathrm{~b}$ & $1606.25 \mathrm{~m}$ & $1532.06 \mathrm{~m}$ & $1435.82 \mathrm{w}$ & $1211.94 \mathrm{~m}$ & $1129.63 \mathrm{~s}$ \\
\hline
\end{tabular}

stretching vibration in the spectrum of the ligand was observed to have shifted to lower wavelength with reduction in intensity, in $\mathrm{Mn}(\mathrm{II}), \mathrm{Pt}(\mathrm{II})$ and $\mathrm{Zn}$ (II) complexes. The observation could be as a result of coordination of the $\mathrm{OH}$ vibration group to the metal ions in the complexes. However, the peak was observed at higher wavelength in $\mathrm{Fe}(\mathrm{II})$ and $\mathrm{Pd}(\mathrm{II})$ complexes (3396.89 and $3384.43 \mathrm{~cm}^{-1}$, respectively). The higher wavelength observed, coupled with broadness of the peak, is as a result of the coordination to the central metal through in enol form.

A strong and broad band at $3384.43 \mathrm{~cm}^{-1}$ attributed to the $\mathrm{CO}$ stretching vibration in the spectrum of $\mathrm{H}_{3} \mathrm{~L}^{1}$ also appeared in the spectral of the metal complexes with significant changes in wavelength and intensity due to effect of the coordination. The peak appeared as

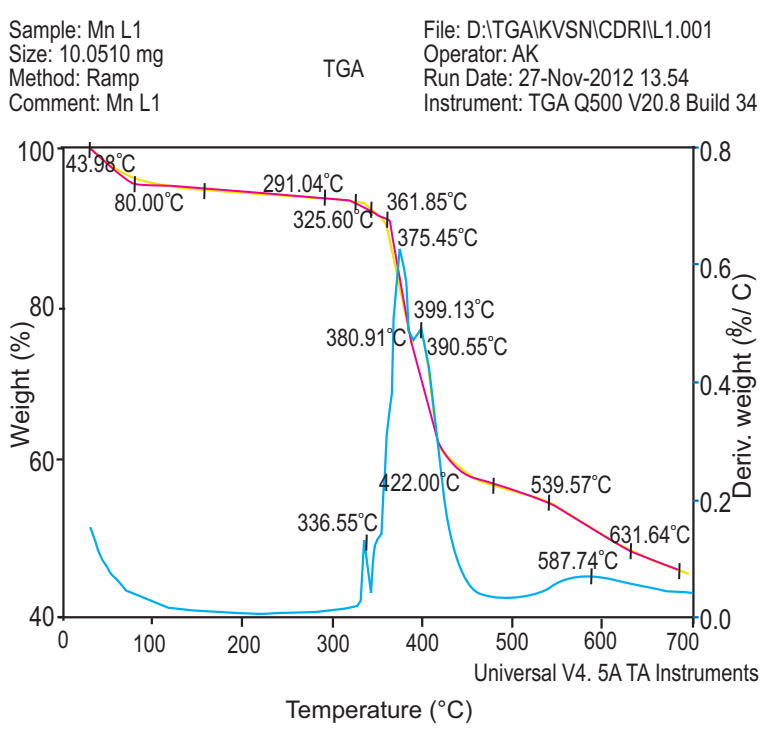

Fig. 8. TGA/DTA spectrum of $\left[\mathrm{Mn}\left(\mathrm{H}_{3} \mathrm{~L}^{1}\right)\left(\mathrm{CH}_{3}\right.\right.$ $\left.\mathrm{COO})_{2}\right] \cdot \mathrm{H}_{2} \mathrm{O}(\mathbf{1})$. a medium peak at the lower wavelength in all of the complexes except in $\mathrm{Mn}$ (II) complex where it appeared at $1660.01 \mathrm{~cm}^{-1}$. The observation could be attributed to the coordination of $\mathrm{CO}$ to the central metal in the complexes.

The azomethine band, which appeared in the spectrum of $\mathrm{H}_{3} \mathrm{~L}^{1}$ at $1508.62 \mathrm{~cm}^{-1}$ as a medium band, appeared in all of the metal complexes at a higher wavelength. The increase in $v(C=N)$ in the spectra of metal complexes is due to the increase in the double bond character off-setting the loss of electron density via donation to the central metal and thus further confirmed the coordination of $\mathrm{H}_{3} \mathrm{~L}^{1}$ through the azomethine atom. The conjugate effect of the coordination through $v(\mathrm{C}=\mathrm{N})$ in the complexes was noticed on $v(\mathrm{~N}-\mathrm{N})$ bands which appeared as weak band in the metal complexes.

UV/Visible spectra. The electronic absorption data of the ligand and the metal complexes in methanol at ambient temperature are recorded in Table 3. The electronic transitions were interpreted by comparing the spectrum of the ligand to the spectra of the corresponding metal complexes. $\mathrm{Mn}(\mathrm{II})$ is of $d^{5}$ configuration which is high spin complex with doubly forbidden transition. Tunabe-Sugano diagram shows that the Russell-Saunders term for $d^{5}$ high spin system is ${ }^{6} S$ with ${ }^{6} \mathrm{~A}_{1 \mathrm{~g}}$ as the ground term symbol. This term gives rise to $4 \mathrm{G}, 4 \mathrm{D}$ and $4 \mathrm{P}$ excited states. Thus, there is no sextet spin multiplicity for octahedral complexes, the transitions are Laporte forbidden and spin forbidden. In the spectrum of the Mn(II) complexes, five notable transition were observed. The high intense transitions at ca. 44248, 33333 and $30864 \mathrm{~cm}^{-1}$ were due to transition of ligand chromophoric groups in the complex. The transition had undergone bathochromic shift toward visible region due to coordination effect. However, two low intense forbidden transitions were observed in 
Mn(II) complex at ca 24390 and $19920 \mathrm{~cm}^{-1}$. They were assigned to ${ }^{4} \mathrm{~T}_{1 \mathrm{~g}}(\mathrm{G}) \leftarrow{ }^{6} \mathrm{~A}_{1 \mathrm{~g}}$ and ${ }^{4} \mathrm{~T}_{1 \mathrm{~g}}(\mathrm{G}) \leftarrow{ }^{6} \mathrm{~A}_{1 \mathrm{~g}}$, respectively which is the characteristics of octahedral geometry but the presence of a weak shoulder at ca $24390 \mathrm{~cm}^{-1}$ suggested a distorted tetrahedral pyramidal complex. This could be pictured as octahedral complex with one corner occupied by a lone pair of electrons (Brik et al., 2011).

The absorption spectrum of Fe(II) complex adapted greatly to the literatures (Munde et al., 2012). Only one band with low intensity was observed in the visible region at ca. $22124 \mathrm{~cm}^{-1}$. This showed that $\mathrm{Fe}$ (II) is of $d^{6}$ configuration with high spin system and ground term symbol of ${ }^{5} \mathrm{D}$. The $d-d$ transition observed was assigned to ${ }^{2} \mathrm{Al}_{2} \leftarrow{ }^{2} \mathrm{~B}_{2}$. However, two absorptions at ca. 33113 and ca. $27700 \mathrm{~cm}^{-1}$ were attributed to $\mathrm{n} \rightarrow \pi^{*}$ transitions in the ligand. The band at ca. $40816 \mathrm{~cm}^{-1}$ was assigned to $n \rightarrow \pi^{*}$ transition in the ligand had completely disappeared while bathochromic shift was observed in $n \rightarrow \pi *$ transition. The observation was attributed to the coordination of the ligand to the metal ion in the complexes.

Table 3. UV/Visible data of $\mathrm{H}_{3} \mathrm{~L}^{1}$ and its metal complexes

\begin{tabular}{|c|c|c|c|}
\hline Compound & $\begin{array}{l}\text { Transition } \\
\mathrm{cm}^{-1}\end{array}$ & $\begin{array}{l}\text { Ground } \\
\text { term } \\
\text { symbol }\end{array}$ & Transition \\
\hline $\mathrm{H}_{3} \mathrm{~L}^{1}$ & $\begin{array}{l}40816 \\
33113 \\
29940\end{array}$ & - & $\begin{array}{l}\pi \rightarrow \pi *(\mathrm{C}=\mathrm{C}) \text { ar } \\
\mathrm{n} \rightarrow \pi^{*}(\mathrm{C}=\mathrm{N}) \\
\mathrm{n} \rightarrow \pi^{*}(\mathrm{C}=\mathrm{O})\end{array}$ \\
\hline $\begin{array}{l}\mathrm{Mn}\left(\mathrm{H}_{3} \mathrm{~L}^{1}\right)\left(\mathrm{CH}_{3}\right. \\
\left.\mathrm{COO})_{2}\right] \mathrm{H}_{2} \mathrm{O}(\mathbf{1})\end{array}$ & $\begin{array}{l}44248 \\
33333 \\
30864 \\
24390 \\
19920\end{array}$ & ${ }^{6} \mathrm{~S}$ & $\begin{array}{l}\pi \rightarrow \pi^{*}(\mathrm{C}=\mathrm{C}) \text { ar } \\
\mathrm{n} \rightarrow \pi^{*}(\mathrm{C}=\mathrm{N}) \\
\mathrm{n} \rightarrow \pi^{*}(\mathrm{C}=\mathrm{O}) \\
{ }^{4} \mathrm{~T}_{1} \mathrm{~g}(\mathrm{G}) \leftarrow{ }^{6} \mathrm{~A} 1 \mathrm{~g} \\
{ }^{4} \mathrm{~T}_{2} \mathrm{~g}(\mathrm{G}) \leftarrow{ }^{6} \mathrm{~A} 1 \mathrm{~g}\end{array}$ \\
\hline$\left[\mathrm{Fe}\left(\mathrm{H}_{3} \mathrm{~L}^{1}\right) \mathrm{Cl}_{2}\right]$ (2) & $\begin{array}{l}33113 \\
27700 \\
22124\end{array}$ & ${ }^{5} \mathrm{D}$ & $\begin{array}{l}\mathrm{n} \rightarrow \pi^{*}(\mathrm{C}=\mathrm{N}) \\
\mathrm{n} \rightarrow \pi^{*}(\mathrm{C}=\mathrm{O}) \\
{ }^{2} \mathrm{~A}_{2} \leftarrow{ }^{2} \mathrm{~B}_{2}\end{array}$ \\
\hline $\mathrm{Pt}\left(\mathrm{H}_{3} \mathrm{~L}^{1}\right)_{2} \cdot \mathrm{Cl}_{2}$ (3) & $\begin{array}{l}33003 \\
28818 \\
16891\end{array}$ & ${ }^{3} \mathrm{D}$ & $\begin{array}{l}\mathrm{n} \rightarrow \pi^{*} \\
{ }^{1} \mathrm{Eg} \leftarrow{ }^{1} \mathrm{~A}_{1} \mathrm{~g} \\
{ }^{1} \mathrm{~A}_{2} \mathrm{~g} \leftarrow{ }^{1} \mathrm{~A}_{1} \mathrm{~g}\end{array}$ \\
\hline $\begin{array}{l}\left.\mathrm{Zn}\left(\mathrm{HL}^{1}\right)_{2}\right)\left(\mathrm{CH}_{3}\right. \\
\mathrm{COO})_{2} \text { (4) }\end{array}$ & $\begin{array}{l}36232 \\
30211 \\
23256\end{array}$ & ${ }^{1} \mathrm{~S}$ & $\begin{array}{l}\mathrm{n} \rightarrow \pi^{*}(\mathrm{C}=\mathrm{N}) \\
\mathrm{n} \rightarrow \pi^{*}(\mathrm{C}=\mathrm{O}) \\
\text { MLCT }\end{array}$ \\
\hline $\mathrm{Pd}\left(\mathrm{HL}^{1}\right)_{2} \cdot \mathrm{Cl}_{2}(\mathbf{5})$ & $\begin{array}{l}42373 \\
31646 \\
26316\end{array}$ & ${ }^{1} \mathrm{~S}$ & $\begin{array}{l}\pi \rightarrow \pi^{*}(\mathrm{C}=\mathrm{C}) \text { ar } \\
\mathrm{n} \rightarrow \pi^{*}(\mathrm{C}=\mathrm{N}) \\
\mathrm{n} \rightarrow \pi^{*}(\mathrm{C}=\mathrm{O})\end{array}$ \\
\hline
\end{tabular}

Magnetic moment data of Pt(II) complex indicate that the complex is a diamagnetic with $d^{8}$ configuration which favours square-planar geometry (Brik et al., 2011). This is also supported by a failed attempt to get the esr data for the complex. The electronic spectrum of the complex showed transition bands at ca. 33003, 28818 and $16891 \mathrm{~cm}^{-1}$. The strong band at ca. 33003 $\mathrm{cm}^{-1}$ was attributed to the $\mathrm{n} \rightarrow \pi^{*}$ transitions in the coordinated ligand while the bands at ca. 28818 and $16891 \mathrm{~cm}^{-1}$ were assigned to ${ }^{1} \mathrm{Eg} \leftarrow{ }^{1} \mathrm{~A}_{1 \mathrm{~g}}$ and ${ }^{1} \mathrm{~A}_{2 \mathrm{~g}} \leftarrow$ ${ }^{1} \mathrm{~A}_{1 \mathrm{~g}}$ transitions.

The electronic spectrum of $\mathrm{Zn}$ (II) complex showed a shoulder band at ca. $362232 \mathrm{~cm}^{-1}$ which was assigned to the $\mathrm{n} \rightarrow \pi^{*}$ transition within the ligand moiety. Also the spectrum showed a strong band at ca. $30211 \mathrm{~cm}^{-1}$. This was assigned to the $\mathrm{n} \rightarrow \pi^{*}$ transition which could be as a result of cumulative effect of transitions of azomethine and amide chromophoric groups of the ligand. The bathochromic shift observed was attributed to the coordination effect. $\mathrm{Zn}$ (II) ion is of $d^{10}$ configuration, therefore no $d-d$ transition is expected, but metal-ligand charge transfer band was observed at ca. $23256 \mathrm{~cm}^{-1}$ due to yellow colour of the complex. No appreciable band was observed below ca. $20,000 \mathrm{~cm}^{-1}$ which is in accordance with $d^{10}$ configuration of $\mathrm{Zn}$ (II) ion.

The Pd(II) ion has a $d^{10}$ configuration with a term symbol, ${ }^{1} \mathrm{~S}$. Due to the filled state of the $d$ - orbital, $d$ - $d$ transition was not observed for Pd(II) complex as expected. However, intra-ligand bands were observed with hypsochromic shift for $\mathrm{n} \rightarrow \pi^{*}$ transition and bathcromic shift for $\mathrm{n} \rightarrow \pi^{*}$ transitions. Thus, support the coordination of the ligand to the central metal ion in the complex.

TGA/DTA analysis. The thermal behaviour of compounds (1), (2) and (5) was investigated by using a non-isothermal thermo gravimetric, $\mathrm{TG}$, and differential TG. The samples were heated at a rate of $10{ }^{\circ} \mathrm{C} \mathrm{min}^{-1}$ under $\mathrm{N}_{2}$ atmosphere from $0-700{ }^{\circ} \mathrm{C}$. The selected thermograms obtained are as represented in Fig. 8. The TG/DTG curve of compound (1) showed $4 \%$ weight loss between 43 and $160{ }^{\circ} \mathrm{C}$. This corresponds to loss of water molecule which is outside the coordination sphere of the complex (Artur et al., 2013). However, the thermogram shows three major decomposition steps. The first step occurred between 291 and $352{ }^{\circ} \mathrm{C}(3 \%$ weight loss). This corresponds to loss of uncoordinated hydroxyl group in the complex. The major weight loss 
occurred in the second step is attributed to a loss of $2 \mathrm{CH}_{3} \mathrm{CO}$ between $361-475{ }^{\circ} \mathrm{C}$. The remaining part of the ligand decomposed to metal oxide in the third step $\left(475-676^{\circ} \mathrm{C}\right)$ of the decomposition.

The TGA/DTA curves for compound (2) shows one major decomposition in Fig. 9. The stability range extended from ambient temperature to $225^{\circ} \mathrm{C}$. The decomposition of the complex occurred in three stages as indicated by DTA peaks at 367,557 and $595^{\circ} \mathrm{C}$. The first decomposition started at $225^{\circ} \mathrm{C}$ and ended at $475^{\circ} \mathrm{C}$. This corresponded to $57 \%$ (Calcd. $58 \%$ ) of the weight loss for the compound which is mainly the $\mathrm{H}_{3} \mathrm{~L}^{1}$ ligand. The second and the third steps were attributed to the loss of the coordinated chloride atoms. This occurred between 530 and $575{ }^{\circ} \mathrm{C}$ and 575 and $625^{\circ} \mathrm{C}$ with a weight loss of $8.7 \%$ (Calcd. $9 \%$ ) in each step. The $\%$ weight of the residue, which was assumed to be the metal oxide, is $23 \%$ (Calcd. of $24 \%$ ).

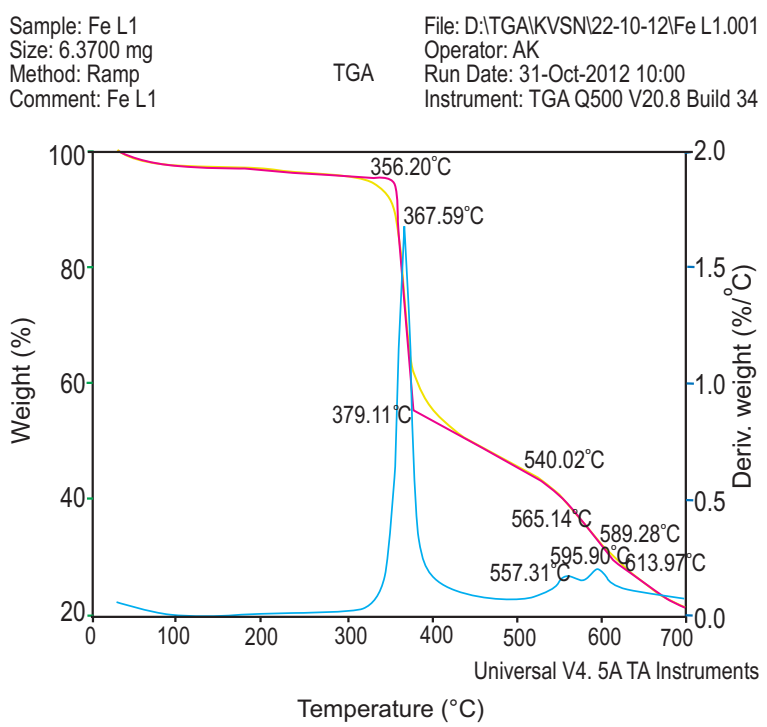

Fig. 9. TGA/DTA spectrum of $\left[\mathrm{Fe}\left(\mathrm{H}_{3} \mathrm{~L}^{1}\right) \mathrm{Cl}_{2}\right]$ (2).

The TGA/DTA curves for compound (5) (Fig. 10) shows an endothermic peak at $102{ }^{\circ} \mathrm{C}$ which indicates the presence of water molecules outside the coordinated sphere of the complex. The $8 \%$ (Calcd. $7.7 \%$ ) weight loss occurred between 88 and $161{ }^{\circ} \mathrm{C}$ is accounted for the loss of the water molecule. Decompositions observed between 220 and $340{ }^{\circ} \mathrm{C}$; and 340 and $465{ }^{\circ} \mathrm{C}$ are attributed to the partial loss of the coordinated ligand in the complex. As thermogram shows, the complex did not decompose fully to the residue within the temperature range of study.

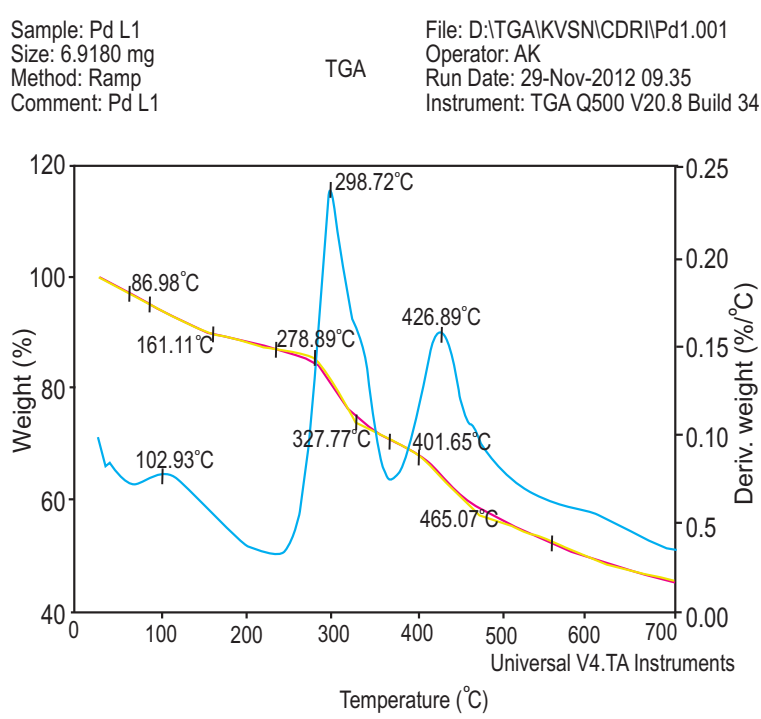

Fig. 10. TGA/DTA spectrum of $\left[\mathrm{Pd}\left(\mathrm{H}_{3} \mathrm{~L}^{1}\right) \mathrm{Cl}\right] \mathrm{H}_{2} \mathrm{O}$ (5).

Electron paramagnetic resonance study. The EPR spectra of $\mathrm{Mn}$ (II) and $\mathrm{Fe}(\mathrm{II})$ complexes were recorded in liquid nitrogen at $77 \mathrm{~K}$. Mn(II) complexes show wide range of geometry. Reports by Charles and Horacia1 (999); Hamed and Neilands (1994) and Pilbrow (1990) have reported that EPR have been used successfully to affirm the geometries of $\mathrm{Mn}(\mathrm{II})$ complexes. The EPR spectrum of $\left[\mathrm{Mn}\left(\mathrm{H}_{3} \mathrm{~L}^{1}\right)\left(\mathrm{CH}_{3} \mathrm{COO}\right)_{2}\right] \mathrm{H}_{2} \mathrm{O}$ in frozen DMSO at $77 \mathrm{~K}$ exhibited $2 \mathrm{~g}$ values at $\mathrm{g}_{\perp}=1.7445$ and $\mathrm{g} \|=2.1240$ with no hyperfine splitting (Fig. 11). The $\mathrm{g}_{\mathrm{av}}$ isotropic value was found to be 2.0569 . This value is very close to the free electron spin value of 2.0023 . This is consistent with the typical manganese (II) ion and could be responsible for the absence of spin orbital coupling in the ground state ${ }^{6} \mathrm{~A}_{1}$ without any sextet term of higher energy (Charles and Horacia,1999; Pilbrow, 1990). The spectrum is broad spectrum which is probably due to polar interactions and enhanced spin lattice relaxation in the complex. The observed $g \|>\mathrm{g}_{\perp}>2$ suggested a monomeric complex with tetrahedral pyramidal geometry.

The spectrum of $\left[\mathrm{Fe}\left(\mathrm{H}_{3} \mathrm{~L}^{1}\right) \mathrm{Cl}_{2}\right]$ in frozen DMSO at 77 $\mathrm{K}$ shows hyperfine splitting with $\mathrm{g}_{\text {iso }}=2.0204, \mathrm{~g}_{\perp}=$ 1.9937 and $g \|=1.9865$ (Fig. 12). The spectrum hyperfine splitting constants, $\mathrm{A} \|$ and $\mathrm{A}_{\perp}$ were found to be $14 \mathrm{mT}$ and $8 \mathrm{mT}$, respectively. The splitting pattern suggested 
pentagonal coordinated environment for $\mathrm{d}^{6} \mathrm{Fe}(\mathrm{II})$ in the complexes (Huang and Haight Jun, 1969). However, since $g_{\perp}>g \|$ and $A \|>A_{\perp}$, which is the characteristic of tetrahedral base complex, the complex was considered to be tetrahedral base pyramidal.

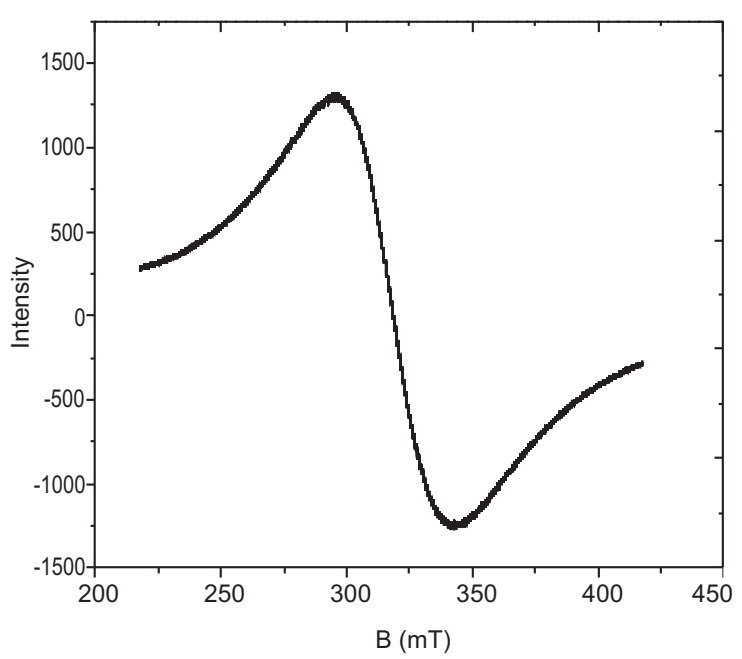

Fig. 11. EPR spectrum of $\left[\mathrm{Mn}\left(\mathrm{H}_{3} \mathrm{~L}^{1}\right)\left(\mathrm{CH}_{3} \mathrm{COO}\right)_{2}\right]$ $\mathrm{H}_{2} \mathrm{O}$.

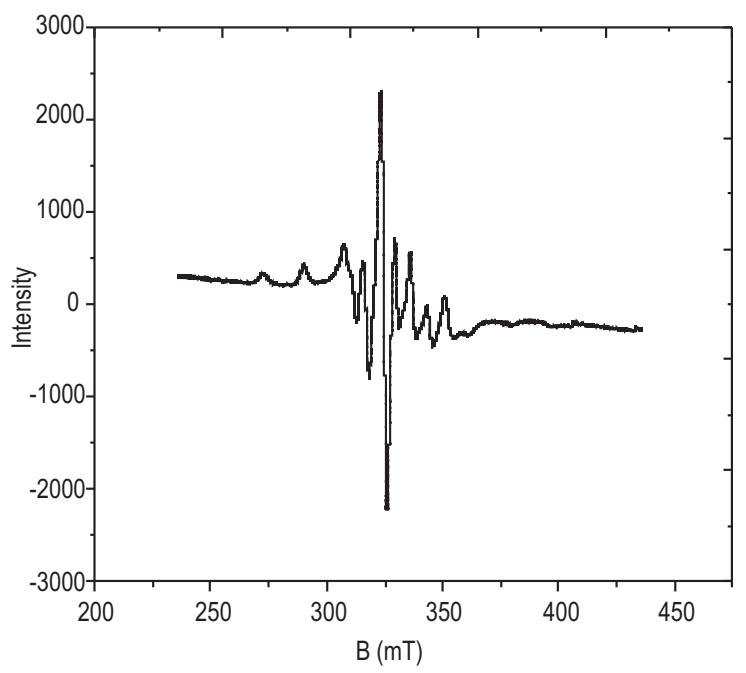

Fig. 12. EPR spectrum of $\left[\mathrm{Fe}\left(\mathrm{H}_{3} \mathrm{~L}^{1}\right) \mathrm{Cl}_{2}\right]$ in DMSO at $77 \mathrm{~K}$.

Powder X-ray diffraction study. The powder XRD pattern for $\left[\mathrm{Mn}\left(\mathrm{H}_{3} \mathrm{~L}^{1}\right)\left(\mathrm{CH}_{3} \mathrm{COO}\right)_{2}\right] \mathrm{H}_{2} \mathrm{O}$ recorded on a Bruker AXS D8 advance diffractometer operating in the $\theta: \theta$ mode, equipped with a secondary beam graphite monochromator is shown in Fig. 13. Table 4 shows the selected diffraction data obtained which were indexed (Hesse, 1948). Mn(II) complex was scanned between $5^{\circ}$ and $120^{\circ}$ at a wavelength of $1.543 \AA$. The diffractograms and associated data depict the $2 \theta$ value for each peak, the relative intensity and inter-planar spacing (d-values). The X-ray diffraction patterns of the complex with respect to major peaks of relative intensity greater than $10 \%$ were indexed using a computer programme (Kozakov et al., 2011; Harikumaran and Thankamani, 2009). The selected indexed data yielded the Miller indices (hkl), the unit cell parameters and the unit cell volume. The unit cell of $\mathrm{Mn}$ (II) complex yielded values of lattice constants: $\mathrm{a}=12.441 \AA, \mathrm{b}=14.582 \AA$ and $\mathrm{c}$ $=7.842 \AA$, and a unit cell volume $\mathrm{V}=1227.2353 \AA^{3}$. In concurrence with these cell parameters, conditions such as $\mathrm{a} \neq \mathrm{b} \neq \mathrm{c}$ and $\alpha=\gamma=90^{\circ} \neq \beta$ required for a monoclinic sample were tested and found to be satisfactory. Hence, it can be concluded that $\left[\mathrm{Mn}\left(\mathrm{H}_{3} \mathrm{~L}^{1}\right)\left(\mathrm{CH}_{3} \mathrm{COO}\right)_{2}\right] \mathrm{H}_{2} \mathrm{O}$ complex has a monoclinic crystal system.

Antimycobacterial results. Based on the results of the biological studies, it was found that the complexes $\left(\mathrm{PtL}^{1}\right)(\mathrm{MIC}=0.56 \mu \mathrm{g} / \mathrm{mL}),\left(\mathrm{ZnL}^{1}\right)(\mathrm{MIC}=0.61$ $\mu \mathrm{g} / \mathrm{mL}),\left(\mathrm{MnL}^{1}\right)(\mathrm{MIC}=0.71 \mu \mathrm{g} / \mathrm{mL})$ and $\left(\mathrm{FeL}^{1}\right)(\mathrm{MIC}$ $=0.82 \mu \mathrm{g} / \mathrm{mL}$ ), exhibited a significant activity when compared with first line drugs such as isoniazid (INH) (MIC $=0.9 \mu \mathrm{g} / \mathrm{mL})$. These results suggest that they may be selectively targeted to M. tuberculosis growth. They are therefore regarded as potential drug candidates but the results of the toxicity study indicated that the complexes are more toxic than the isoniazid and the ligand. However, $\mathrm{Fe}(\mathrm{II})$ complex of $\mathrm{H}_{3} \mathrm{~L}^{1}$ displayed the

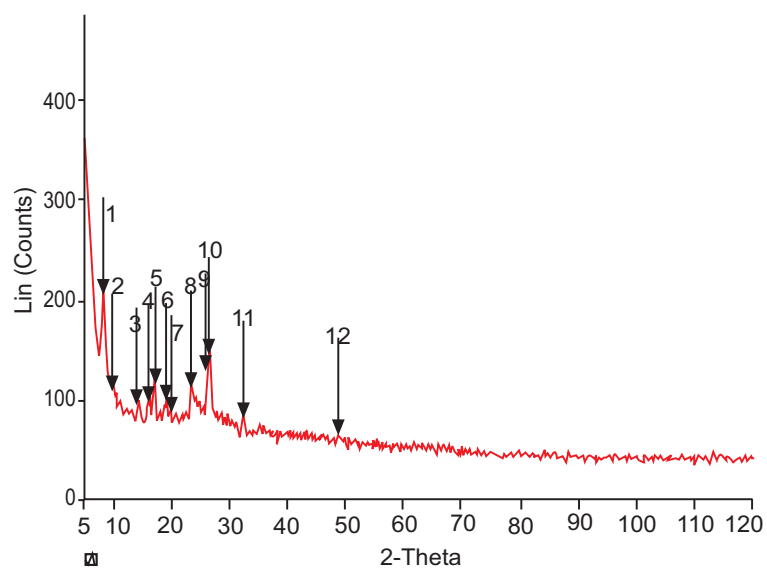

Fig. 13. X-ray diffraction pattern of $\left[\mathrm{Mn}\left(\mathrm{H}_{3} \mathrm{~L}^{1}\right)\right.$ $\left.\left(\mathrm{CH}_{3} \mathrm{COO}\right)_{2}\right] \mathrm{H}_{2} \mathrm{O}(\mathbf{1})$. 


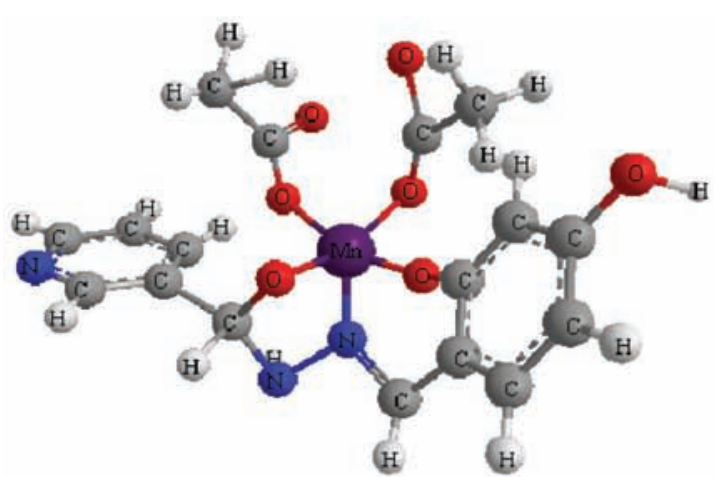

$\left[\mathrm{Mn}\left(\mathrm{H}_{3} \mathrm{~L}^{1}\right)\left(\mathrm{CH}_{3} \mathrm{COO}\right)_{2}\right] \mathrm{H}_{2} \mathrm{O}(1)$

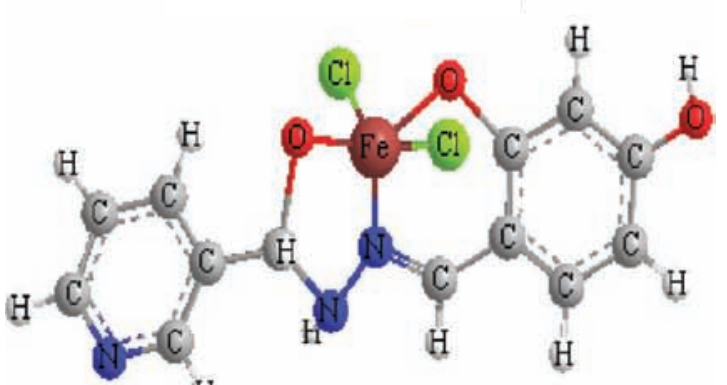

$\mathrm{H}$

$\left[\mathrm{Fe}\left(\mathrm{H}_{3} \mathrm{~L}^{1}\right)\left(\mathrm{Cl} \mathrm{Cl}_{2}\right)\right](2)$
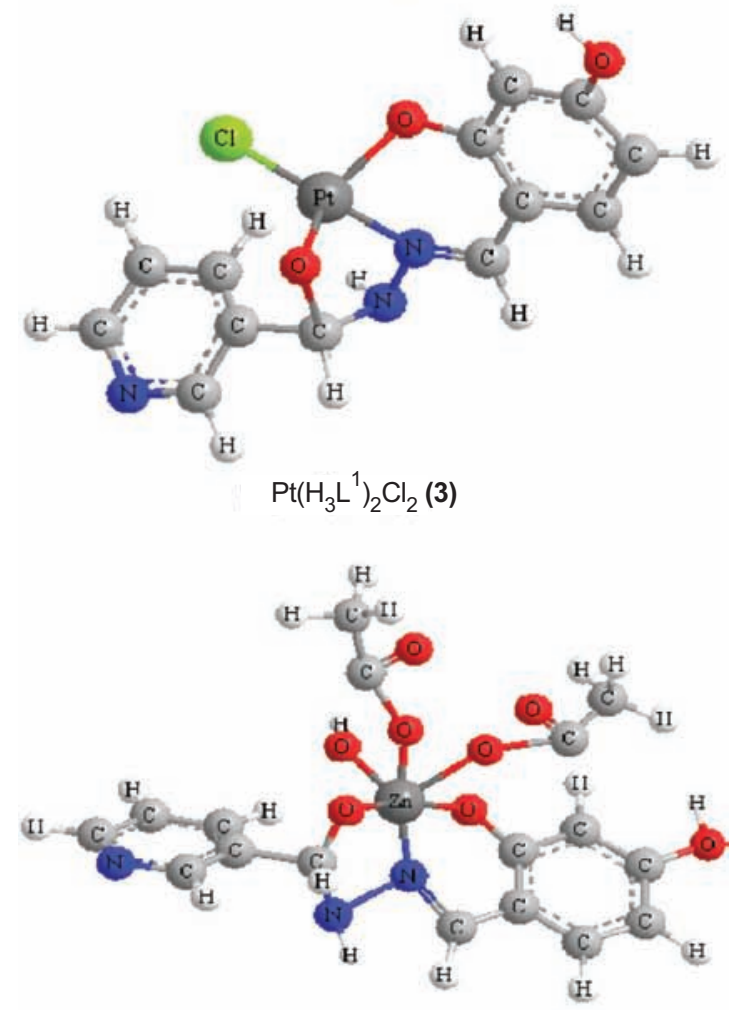

$\mathrm{Zn}\left(\mathrm{H}_{3} \mathrm{~L}^{1}\right)_{2}\left(\mathrm{CH}_{3} \mathrm{OO}\right)_{2}(4)$

Fig. 14. The proposed structures for the complexes. lowest toxicity with the $\mathrm{IC}_{50}$ value of $0.92 \mu \mathrm{M}$ which were found to be non significant different $(\mathrm{P}>0.05)$ to that of the ligand $\left(\mathrm{H}_{3} \mathrm{~L}^{1}\right)\left(\mathrm{IC}_{50}=3.01 \mu \mathrm{g} / \mathrm{mL}\right)$ and isoniazid ( $\mathrm{INH})\left(\mathrm{IC}_{50}=4.72 \mu \mathrm{M}\right)$. The results obtained were displayed in bar chart (Fig. 15).

Table 4. X-ray powder diffraction data for $\left[\mathrm{Mn}\left(\mathrm{H}_{3} \mathrm{~L}^{1}\right)\right.$ $\left.\left(\mathrm{CH}_{3} \mathrm{COO}\right)_{2}\right] \mathrm{H}_{2} \mathrm{O}(\mathbf{1})$

\begin{tabular}{lllllll}
\hline \hline $2 \theta$ & $\mathrm{d}(\AA)$ & Count & $\begin{array}{l}\text { Intensity } \\
\text { count }(\%)\end{array}$ & $\mathrm{h}$ & $\mathrm{k}$ & $\mathrm{l}$ \\
\hline 8.076 & 10.9383 & 212 & 10.9 & 1 & 0 & 0 \\
9.393 & 5.5773 & 105 & 5.57 & 4 & 9 & 8 \\
13.865 & 3.8474 & 115 & 3.84 & 5 & 4 & 5 \\
16.800 & 3.1415 & 162 & 42.2 & 1 & 0 & 0 \\
18.724 & 2.6809 & 166 & 43.2 & 1 & 0 & 0 \\
19.790 & 2.5411 & 155 & 40.3 & 1 & 1 & 0 \\
23.098 & 1.3748 & 95.8 & 24.9 & 2 & 0 & 0 \\
25.738 & 1.3420 & 92.7 & 24.1 & 2 & 1 & 0 \\
25.993 & 1.15342 & 93.2 & 24.2 & 2 & 2 & 0 \\
32.067 & 1.04703 & 86 & 22.3 & 3 & 0 & 0 \\
48.277 & 0.92321 & 89.4 & 23.2 & 3 & 1 & 1 \\
\hline \hline
\end{tabular}

Table 5. MIC $(\mu \mathrm{g} / \mathrm{mL})$ and $\mathrm{IC}_{50}(\mu \mathrm{M})$ values of the metal complexes of $\mathrm{H}_{3} \mathrm{~L}^{1}$

\begin{tabular}{lll}
\hline \hline Entry & $\begin{array}{l}\mathrm{MIC} \\
(\mu \mathrm{g} / \mathrm{mL})\end{array}$ & $\begin{array}{l}\mathrm{IC}_{50} \\
(\mu \mathrm{M})\end{array}$ \\
\hline $\mathrm{MnL}^{1}$ & 0.71 & 0.85 \\
$\mathrm{FeL}^{1}$ & 0.82 & 0.92 \\
$\mathrm{PtL}^{1}$ & 0.56 & 1.03 \\
$\mathrm{ZnL}^{1}$ & 0.61 & 1.17 \\
$\mathrm{H}_{3} \mathrm{~L}^{1}$ & 1.02 & 3.01 \\
$\mathrm{INH}$ & 0.92 & 4.72 \\
\hline \hline
\end{tabular}

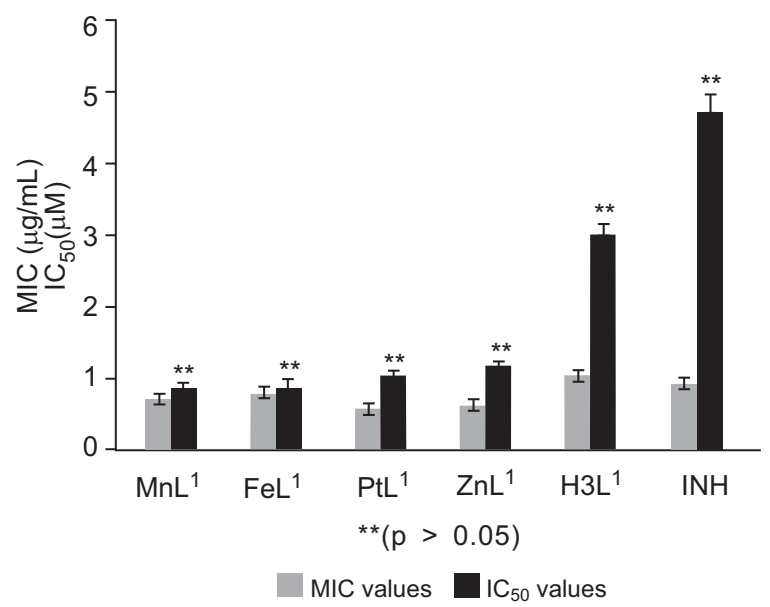

Fig. 15. Comparison of MIC/IC50 values of the metal complexes with the ligand and isoniazid drug. 


\section{Conclusion}

In conclusion, $\mathrm{H}_{3} \mathrm{~L}^{1}$ was successfully synthesized at $20^{\circ} \mathrm{C}$ from nicotinic hydrazide by stirring in the presence of 2,4-dihydroxybenzaldehyde. The hydrazone is a derivative of isoniazid and therefore was expected to possess antitubercular activity. The structure of the hydrazone was successfully elucidated by using mass spectrum, CHN analysis, ${ }^{1} \mathrm{H},{ }^{13} \mathrm{C}$ and 2D NMR. All the efforts made to grow single crystals of the metal complexes did not yield positive results. Hence, the physical properties and structures of the metal complexes were elucidated using different spectroscopic analysis. The information obtained was supported with the use of powder X-ray analysis which leads to the model structures of the complexes. The in vitro antitubercular study confirmed the efficacies of the compounds. The metal complexes were found to be more active than isoniazid however, they were found to be more toxic against the vero cell than isoniazid.

\section{Acknowledgement}

The authors express their gratitude to CISR and TWAS for financial support through TWAS-CSIR fellowship granted to carry out this work. We thank all the staff of SAIF Central Drug Research Institute, Lucknow, Indian Institute of Technology, Roorkee, and Indian Institute of Technology, Bombay, India for their technical support.

\section{References}

Aboul-Fadl, T., Abdel-Aziz, H.A., Abdel-Hamid, M.K., Elsaman, T., Jane Thanassi, J., Pucci, M.J. 2011. Schiff bases of indoline-2,3-dione: potential novel inhibitors of Mycobacterium tuberculosis (Mtb) DNA gyrase. Molecules, 16: 7864-7879.

Al-Shaalan, N.H. 2011. Synthesis, characterization and biological activities of $\mathrm{Cu}(\mathrm{II}), \mathrm{Co}(\mathrm{II}), \mathrm{Mn}(\mathrm{II}), \mathrm{Fe}(\mathrm{II})$, and $\mathrm{UO}_{2}(\mathrm{VI})$ Complexes with a new schiff base hydrazone: $O$-hydroxyacetophenone-7-chloro-4quinoline hydrazone. Molecules, 16: 8629-8645.

Belskaya, N.P., Dehaen, W., Bakuleva, V.A. 2010. Synthesis and properties of hydrazones bearing amide, thioamide and amidine functions. Journal of Organic Chemistry 2010: 275-332.

Berger, S., Sicker, D. (eds.), 2009. Classics in Spectroscopy, Isolation and Structure Elucidation of Natural Products, vol. 72: 117 pp., Wiley-VCH, Germany. Brik, M.G., Srivastava, A.M., Avram, N.M. 2011. Comparative analysis of crystal field effects and optical spectroscopy of six-coordinated $\mathrm{Mn}^{4+}$ ion in the $\mathrm{Y}_{2} \mathrm{Ti}_{2} \mathrm{O}_{7}$ and $\mathrm{Y}_{2} \mathrm{Sn}_{2} \mathrm{O}_{7}$ pyrochlores. Optical Materials, 33: 1671-1676.

Charles, P.P., Horacia, A.F. 1999. Handbook of Electron Spin Resonance. 123 pp. Springer-Verlag Inc. New York, USA.

Cui, Y., Dong, X., Li, Y., Li, Z., Chen, W. 2012. Synthesis, structures and urease inhibition studies of Schiff base metal complexes derived from 3, 5dibromosalicylaldehyde. European Journal of Medicinal Chemistry, 58: 323-331.

Davidson, G. 2010. Spectroscopic properties of inorganic and organometallic compounds. Royal Society of Chemistry, 39: 212-226.

De Backer, A.I., Mortelé, K.J., De Keulenaer, B.L., Parizel, P.M. 2006. Tuberculosis: epidemiology, manifestations, and the value of medical imaging in diagnosis. JBR-BTR-Journal, Belge de RadiologieBelgisch Tijdschrift voor Radiologi, 89: 243-250.

Hamed, M.Y., Neilands, J.B. 1994. An electron spin resonance study of the $\mathrm{Mn}$ (II) and $\mathrm{Cu}$ (II) complexes of the Fur repressor protein. Journal of Inorganic Biochemistry, 53: 235-248.

Harper, C. 2007. Tuberculosis, a neglected opportunity? Nature Medicine, 13: 309-312.

Hesse, R. 1948. Indexing powder photographs of tetragonal, hexagonal and orthorhombic. Acta Crystallographica, 1: 200-207.

Huang, T., Haight Jun, J.P.J. 1969. Electron spin resonance studies of monomer-dimer equilibria involving molybdenum $(\mathrm{V})$ complexes with cysteine and glutathione. Journal of the Chemical Society D: 985-986. DOI: 10.1039/C29690000985.

Jenkins, A.O., Cadmus, S.I.B., Venter, E.H., Pourcel, C., Hauk, Y., Vergnaud, G. 2011. Molecular epidemiology of human and animal tuberculosis in Ibadan, South Western Nigeria. Veterinary Microbiology, 151: 139-147.

Jia, L., Tomaszewski, J.E., Hanrahan, C., Coward, L., Noker, P., Gorman, G., Nikonenko, B., Protopopova, M. 2005. Pharmacodynamics and pharmacokinetics of SQ109, a new diamine-based antitubercular drug. British Journal of Pharmacology, 144: 80-87.

Jindani, A., Nunn, A.J., Enarson, D.A. 2004. Two 8-month regimens of chemotherapy for treatment of newly diagnosed pulmonary tuberculosis: International multicentre randomized trial. Lancet, 364: 1244-1251.

Jursic, B.S., Douelle, F., Bowdy, K., Stevens, E.D. 
2002. A new facile method for preparation of heterocyclic $\alpha$-iminonitriles and $\alpha$-oxoacetic acid from heterocyclic aldehydes, $p$-aminophenol, and sodium cyanide. Tetrahedron Letters, 43: 53615365.

Kozakov, A.T., Kochur, A.G., Nikolsky, A.V., Googlev, A.K., Smotrakov, A.G., Eremkin, V.V. 2011. Valence and magnetic state of transition-metal and rareearth ions in single crystal multiferroics $\mathrm{RMn}_{2} \mathrm{O}_{5}$ $(\mathrm{R}=\mathrm{Y}, \mathrm{Bi}, \mathrm{Eu}, \mathrm{Gd})$ from $\mathrm{X}$-ray photoelectron spectroscopy dta. Journal of Electron Spectroscopy and Related Phenomena, 184: 508-516.

Laughon, B.E. 2007. New tuberculosis drugs in development. Current Topics in Medicinal Chemistry, 7: 463-473.

Munde, A.S., Shelke, V.A., Jadhav, S.M., Kirdant, A.S., Vaidya, S.R., Shankarwar, S.G., Chondhekar, T.K. 2012. Synthesis, characterization and antimicrobial activities of some transition metal complexes of biologically active asymmetrical tetradentate ligands. Advances in Applied Science Research, 3: 175-182.

Mustafa, I.M., Hapipah, M.A., Abdulla, M.A., Ward, T.R. 2009. Synthesis, structural characteri-zation, and anti-ulcerogenic activity of schiff base ligands derived from tryptamine and 5-chloro, 5-nitro, 3, 5-ditertiarybutyl salicylaldehyde and their nickel(II), copper(II), and zinc(II) complexes. Polyhedron, 28: 3993-3998.

Nair, H.M.L., Thankamani, D. 2009. Synthesis and characterization of oxomolybdenum(V) and dioxomolybdenium(VI) complexes with Schiff base derived from isonicotinoylhydrazide. Indian Journal of Chemistry, 48 A: 1212-1218.

Patel, N.B., Patel, J.C. 2011. Synthesis and antimicrobial activity of schiff bases and 2-azetidinones derived from quinazolin- 4(3H)-one. Arabian Journal of Chemistry, 4: 403-411.

Pavia, D.L., Lampman, G.M., Kriz, G.S., Vyvyan, J.A. 2008. Introduction to Spectroscopy, 312 pp., $4^{\text {th }}$ edition, Brooks Cole, New York, USA.
Phillip, O., Graham, A.W.R. 2004. Causative agent: Tuberculosis is spread by aerosols from patients with pulmonary disease. Nature Reviews, Microbiology, 2: 930-932.

Pilbrow, J.R. 1990. Transition Ion Electron Paramagnetic Resonance, pp. 12-89, Clarendon Press, Oxford, UK.

Protopopova, M., Hanrahan, C., Nikonenko, B., Samala, R., Chen, P., Gearhart, J., Einck, L., Nacy, C.A. 2005. Identification of a new antitubercular drug candidate, SQ109, from a combinatorial library of 1, 2-ethylenediamines. The Journal of Antimicrobial Chemotherapy, 56: 968-974.

Sacchettini, J.C., Rubin, E.J., Freundlich, J.S. 2008. Drugs versus bugs: in pursuit of the persistent predator Mycobacterium tuberculosis. Nature Reviews, Microbiology, 6: 41-52.

Sankar, R., Vijayalakshmi, S., Rajagopan, S., Kaliyappan, T. 2010. Synthesis, spectral, thermal, and chelation potentials of polymeric hydrazone based on 2, 4dihydroxy benzophenone. Journal of Applied Polymer Science, 117: 2146-2152.

Silverstein, R.M., Webster, F.X. 2002. Spectrometric Identification of Organic Compounds, 216 pp., $6^{\text {th }}$ edition, John Wiley and Sons, India.

Sivakumar, K.K., Rajasekaran, A. 2013. Synthesis, invitro antimicrobial and antitubercular screening of Schiff bases of 3-amino-1-phenyl-4- [2-(4-phenyl1,3-thiazol-2-yl) hydrazin-1-ylidene]-4,5-dihydro1H-pyrazol-5-one. Journal of Pharmacy and Bioallied Sciences, 5: 126-135.

Stefankiewicz, A.R., Walesa-Chorab, M., Harrowfield, J., Kubicki, M., Zbigniew, H., Korabik, M., Patroniak, V. 2013. Self-assembly of transition metal ion complexes of a hybrid pyrazine-terpyridine ligand. Dalton Transitions, 42: 1743-1751.

Stewart, G.R., Robertson, B.D., Young, D.B. 2003. Tuberculosis: a problem with persistence. Nature Reviews, Microbiology, 1: 97-105.

WHO, 2013. Global Tuberculosis Report. World Health Organization, Geneva, Switzerland. 